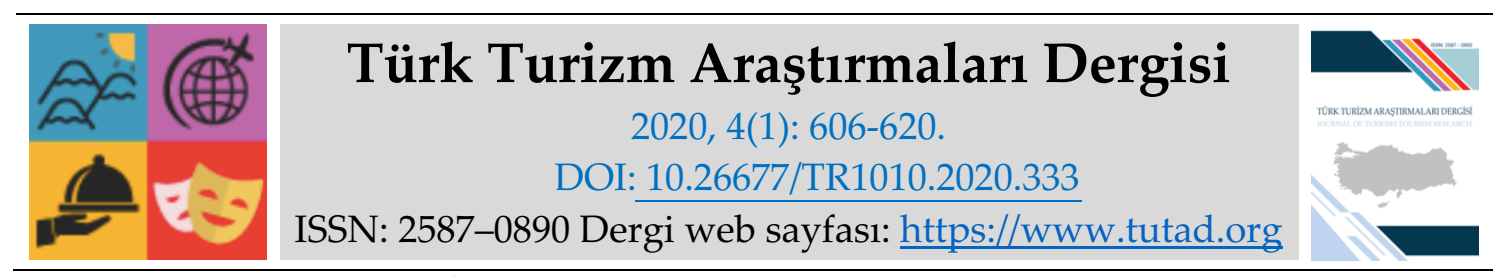

ARASTTIRMA MAKALESI

\title{
Sakin Şehirlerde Sürdürülebilirliğin Metaforik Açıdan Karşılaştırılması
}

Arş. Gör. İbrahim Taner AKKOÇ, Anadolu Üniversitesi, Turizm Fakültesi, Eskişehir, e-posta: ibrahimtanerakkoc@anadolu.edu.tr ORCID: https://orcid.org/0000-0002-2196-3266

Doç. Dr. Emre Ozan AKSÖZ, Anadolu Üniversitesi, Turizm Fakültesi, Eskişehir, e-posta: ozana@anadolu.edu.tr

ORCID: https://orcid.org/0000-0002-4109-8847

\section{$\ddot{O} z$}

Sakin şehirlerin sürdürülebilirliği ile yöreye has değerler arasındaki ilişkinin yerel halk tarafından anlaşılması ve benimsenmesi arasında pozitif yönlü bir ilişki vardır. Bu ilişki anlaşıldıkça sakin şehir hareketinin daha çok benimseneceği, benimsendikçe sakin şehirlerin sürdürülebilirliğinin daha da artacağı ileri sürülebilir. Bu kapsamda çalışmanın amacı Taraklı ve Yalvaç halkının sakin şehir anlayışına yönelik algısını sürdürülebilirliğin boyutları bağlamında metaforik açıdan ölçmektir. Ntel araştırma yöntemiyle yürütülen bu çalışamada durum araştırması yaklaşımı benimsenmiş olup amaçlı örnekleme yöntemlerinden kolay ulaşılabilir durum örneklemesi tercih edilmiştir. Araştırma verileri yarı yapılandırılmış görüşme tekniğiyle 12 kişi üzerinden toplanmıştır. Araştırma bulgularına göre sakin şehir anlayışı konusunda Taraklı halkında kayda değer bir farkındalık oluştuğu buna karşın Yalvaç'ta bu anlayışın yeteri kadar yaygınlaştırılmadığı görülmüştür. Ayrıca sakin şehir anlayışıyla geleneksel el sanatlarının ve yerel ürünlerin değer kazanmaya başlandığı Taraklı'da sürdürülebilir yerel kalkınma, tüm boyutları açısından olumlu yönde seyretmektedir. Buna karşın Yalvaç'ta zorunlu olan ve yöre için önem arz eden sakin şehir kriterlerinin yeteri kadar yaygınlaştırılmadığı ve uygulanmadığı sonucuna ulaşılmıştır. Ayrıca Yalvaç'ta yöreye özgü değerlerin kaybolmaya yüz tuttuğu tespit edilmiştir.

Anahtar Kelimeler: Sürdürülebilir Yerel Kalkınma, Sakin Şehir Hareketi, Metafor, Yalvaç, Taraklı Makale Gönderme Tarihi: 25.11.2019

Makale Kabul Tarihi: 14.01.2020

\section{Önerilen Atıf:}

Akkoç, İ. T. ve Aksöz, E. O. (2020). Sakin Şehirlerde Sürdürülebilirliğin Metaforik Açıdan Karşılaştırılması, Türk Turizm Araştırmaları Dergisi, 4(1): 606-620.

(c) 2020 Türk Turizm Araştırmaları Dergisi. 


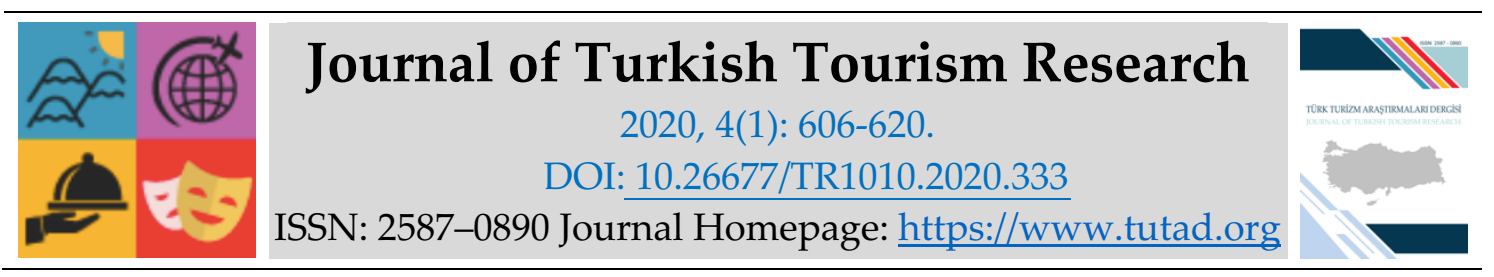

\title{
RESEARCH PAPER
}

\section{Comparison of Sustainability in Cittaslows from a Metaphorical Perspective}

Research Assistant İbrahim Taner AKKOÇ, Anadolu University, Faculty of Tourism, Eskişehir, e-mail: ibrahimtanerakkoc@anadolu.edu.tr

ORCID: https://orcid.org/0000-0002-2196-3266

Associate Prof. Dr. Emre Ozan AKSÖZ, Anadolu University, Faculty of Tourism, Eskişehir, e-mail: ozana@anadolu.edu.tr

ORCID: https://orcid.org/0000-0002-4109-8847

\begin{abstract}
As the relationship between sustainability and local values is understood in cittaslows, the movement is more embraced. The more this understanding is adopted, the greater the sustainability of cittaslows. This study, which aims to measure the perception of Taraklı and Yalvaç people in terms of metaphorical on Cittaslow Movement and dimensions of sustainable development, was carried out with qualitative research method. In this study, where case study research approach is adopted, easy-accessible case sampling is preferred among purposeful sampling methods. The data of the study were collected from 12 people by semi-structured interview technique. According to the findings, it was concluded that there was a considerable awareness among the people of Taraklı about Cittaslow movement, but this movement was not sufficiently expanded in Yalvaç. In addition, sustainable local development for all dimensions in Tarakll, where traditional handicrafts and local products have started to gain value through cittaslow approach, has a positive course. On the other hand, it was concluded that in Yalvaç, the criteria of Cittaslow, which are essential and important for the region, were not sufficiently extended and applied. It was also found that the values of the region are disappearing in Yalvaç.
\end{abstract}

Keywords: Sustainable Local Development, Cittaslow Movement, Metaphor, Yalvaç, Taraklı.

Received: 25.11 .2019

Accepted: 14.01 .2020

\section{Suggested Citation:}

Akkoç, İ. T. and Aksöz, E. O. (2020). Comparison of Sustainability in Cittaslows from a Metaphorical Perspective, Journal of Turkish Tourism Research, 4(1): 606-620.

(C) 2020 Türk Turizm Araştırmaları Dergisi. 


\section{GíRiş}

Endüstri devrimiyle birlikte insanları etkisi altına alan ve yaşam tarzına gözle görülür biçimde yön veren olgulardan bir tanesi de küreselleşmedir. Bu gelişme tek tipleşmeyi zorunlu kılmış ve yerel kültürel değerlerin hızlı bir şekilde ortadan kaybolmasına neden olmuştur (Şahin, 2017: 5). Küreselleşmenin etkileri insanlar arasındaki iletişimi, kaynaşmayı ve değişimi kolaylaştırsa da farklılıkları ortadan kaldırarak tek tip bir insan modeli ortaya koymakta hatta şehirleri de tek tipleştirerek homojen bir yapıya büründürmektedir (Sırım, 2012: 120). Buna bağlı ortaya çıan problemler; kültürel değerlerin yozlaşması, tarihi ve yöresel öğelerin yok olmaya yüz tutması, çevre kirliliği, doğal kaynakların tükenmesi, sosyal adaletsizlik ve ekonomik istikrarsızlık şeklinde sıralanabilir. Bu unsurların yarattığı etkileri ortadan kaldırmanın yolu; sürdürülebilir gelişimi sağlayabilen, çekicilik unsurlarını çeşitlendiren, kaynaklarını en iyi şekilde değerlendiren, yenilik ve yaratıcılı̆̆ı faaliyetlerine yansıtabilen destinasyonları yaratmak (Ekincek, 2014: 2) ya da mevcut olanları bu amaçlar doğrultusunda dönüştürebilmektir.

Sakin Şehir Hareketi kendine özgü sosyo-ekonomik ve sosyo-kültürel değerleri bünyesinde taşıyan ve bu dönüşüme ihtiyacı olan yerleşim yerleri için güncelliğini koruyan önemli bir toplumsal harekettir. Çünkü sakin şehir hareketi; küreselleşmeye karşı sürdürülebilir, adil ve özgün kentsel gelişimi teşvik eden (Semmens Freeman, 2012: 357) yerel ve geleneksel kültürü koruyan, yaşamın rahat ve keyifli bir tempoda devam etmesini savunan, çevresel değerlere sahip çıkan (Tranter, 2010: 158) ve aynı zamanda şehirlerin modernleşme yolunda özlerini kaybetmeden ilerlemesini öngören alternatif bir akımdır (Dogrusoy ve Dalgakiran, 2011: 127).

Sürdürülebilirliğin her boyutu Sakin Şehir kavramına uyarlandığında bu hareket sürdürülebilir kalkınma, sürdürülebilir şehircilik ve sürdürülebilir turizm anlamına gelmektedir. (Karadeniz, 2014: 85). Sürdürülebilir turizm uygulamasının, turistik yerlerin kalkınmasında somut bir kanıt olması sebebiyle yerele dönük uygulamalara daha fazla odaklanma ihtiyacı doğmuştur (UNEP, 2003: 7). Bu şekilde bölgesel kalkınmayı ve gelişmeyi destekleyen ve sürdürülebilirliğe katkı sağlayan ulusal ve uluslararası uygulamalarla turizme yön vermek amaçlanmaktadır. Uluslararası bir ağ olan Sakin Şehir Hareketi de sürdürülebilir turizme katkı sağlayabilecek türden uygulamalar arasında yerini almıştır (Dinçer vd., 2015: 327).

Sakin şehirlerde sürdürülebilir yerel kalkınmanın geldiği noktayı araştırmak sakin şehir uygulamasının etkisini ortaya çıkarmak adına büyük önem arz etmektedir. Bu amaçla ilgili alanda yapılan araştırmalara bakıldığında sürdürülebilir turizm ilkeleriyle sakin şehir kriterlerinin paralellik gösterdiğini ortaya koyan kavramsal çalışmalara rastlanmıştır (Karadeniz, 2014; Güneş, 2015). Bununla birlikte sakin şehir uygulamasının çeşitli açılardan destinasyona etkisini yerel halkın algısı üzerinden inceleyen çalışmaların olduğu da görülmüştür (Andarabi, 2012; Coşar, 2013; Aslan ve Güneş, 2016). Ancak sakin şehir kriterlerini sağlamış destinasyonları sakin şehir felsefesi ve sürdürülebilir yerel kalkınma bağlamında karşılaştıran bir çalışmaya rastlanmamıştır. Bununla birlikte sakin şehir felsefesi ve sürdürülebilir kalkınma boyutları açısından yerel halkın algısını doğrudan metaforik bir öğe olan sakin şehir logosunu kullanarak belirleyen bir çalışmaya da rastlanmamıştır. 


\section{KAVRAMSAL ÇERÇEVE}

Teknoloji ve kitle iletişim araçlarında yaşanan gelişmelere bağlı olarak ekonomik ve kültürel unsurlar sınır tanımadan serbest bir şeklide dünyaya yayılmaktadır. Küreselleşme şeklinde ifade edilen bu süreç hızlı bir yaşamı da beraberinde getirmiştir. Bu durum günümüz toplumları için ekonomik, politik ve kültürel açıdan dikkati çeken bir dönüşüm ve değişime neden olmuştur. Bu gelişmeler 1şığında ürünlerini tüm dünyaya sunabilen Starbucks ve McDonald's gibi küresel işletmeler faaliyete geçmeye başlamıştır. Bu işletmeler hızlı yaşam için tasarlanmış ürünlerini yerel pazarlara sunarak yerel ürünler ve kültürleri tehdit eder bir konuma gelmiştir (Yurtseven, 2010). Yerel değerleri yok eden bu tehdide karşı uluslararası düzeyde ilk tepki İtalyan gastronomi yazarı Carlo Petrini önderliğinde gerçekleşmiştir. McDonal's'ın İtalya'nın tarihi bir bölgesinde restoran açma girişimini İtalyan mutfağına karşı bir tehdit olarak gören Carlo Petrini ve çevresi bu durumu protesto ederek uluslararası bir hareketin temellerini atmışlardır. Başlattıkları hareketin adı Yavaş Yemek Hareketidir (SanderRegier, 2004). Yavaş Yemek Hareketi, yerele ait gastronomi kültürünün ortadan kalmasına ve hızlı yaşamın etkisine karşı koymak için, insanların yediklerinin nereden geldiği ve tercihlerinin dünyayı nasıl etkilediği konusunda oluşan duyarsızlıkla mücadele etmek için ortaya çıkan bir halk hareketidir (www.slowfood.com).

Günümüzde yüz binden fazla üyesi ve yüzden fazla ülke temsilcisiyle küresel bir harekete dönüşen Yavaş Yemek Hareketi, Yavaş Hareketi (Slow Movement) altında yeni yavaş akımlarının ortaya çıkmasına öncülük etmiştir (Ünal ve Zavalsız, 2016). Yavaş Hareketi de benzer şekilde küreselleşmenin ve hızlı yaşamın, sosyo-kültürel ve çevresel ilişkiler üzerindeki olumsuz etkilerine karşı ortaya çıkmıştır (Markwell, Wilson ve Fullagar, 2012). Seyahatten ekonomiye, sosyal ilişkilerden hayat tarzına, yeme içme biçiminden kent yaşamına kadar hızlı tüketim alışkanlıklarını her alanda sorgulayan bu hareket, yerelliği, doğallığı ve insan doğasıyla uyumlu olan yavaşlığı destekleme amacı taşımaktadır (Güven, 2011). Buna göre yaşamın diğer alanlarında gelişmeye başlayan; yavaş işletmecilik, yavaş para, yavaş eğitim, yavaş ticaret, yavaş seyahat, yavaş yemek, yavaş turizm ve sakin şehir gibi yeni akımlar ortaya çıkmaya başlamıştır (Ünal ve Zavalsız, 2016).

Yavaş Yemek Hareketinin kurucusu Carlo Petrini, Yavaş Hareketi anlayışının bir ağ üzerinden kasabalar için de uygulanabileceği fikrini 1997 yılında ilk kez ortaya atmış (Miele, 2008: 136) ve 1999 yılında küçük bir İtalyan kasabasının belediye başkanı Paolo Saturnini, Sakin Şehir Hareketini başlatmıştır (www.cittaslow.org). Sakin Şehir Hareketinin temel amacı, Yavaş Yemek Hareketinin felsefesinde yer alan ekogastronomi konseptini gündelik yaşama uygulayarak yerel topluluklara ve kentsel boyuta taşımaktır (www.cittaslow.org). Çevrenin korunması, sürüdürülebilir kalkınmanın desteklenmesi, kentsel yaşamın iyileştirilmesi üzerine geliştirilen kapsamlı fikirlerle Sakin Şehir Hareketi doğal ve çevre dostu gıda üretiminin teşvik edilmesine katkı sağlar (www.cittaslow.org).

Bir kentin Sakin Şehir Hareketine katılabilmesi için sağlaması gereken kriterler Sakin Şehir Yönetmeliğinde geçen Mükemmelliyet Koşulları başlı̆̆ı altında belirlenmiştir. Harekete dahil olan bir kent, mükemmelliyet koşullarındaki 7 temel alanı kapsayan 72 kriterin en az \%50'ni ve her temel alandan en az bir kriteri yerine getirmesi gerekmektedir (www.cittaslow.org). Sakin Şehir Logosu, bir kentin evlerini ve kulelerini taşıyan sola doğru yönelmiş turuncu renkli bir salyangozdur. Uluslararası Koordinasyon Komitesinin yönetmeliği doğrultusunda hazırlanan ve kullanılabilen logo aynı zamanda birliğin tescilli bir markası ve mirasıdır. Sakin Şehir Hareketinin bir de sloganı vardır. "Yaşamanın güzel olduğu şehirlerin küresel ağı: Sakin Şehir" şeklinde Türkçe'ye çevirilebilen slogan ve logo aşağıda yer almaktadır (www.cittaslow.org). 


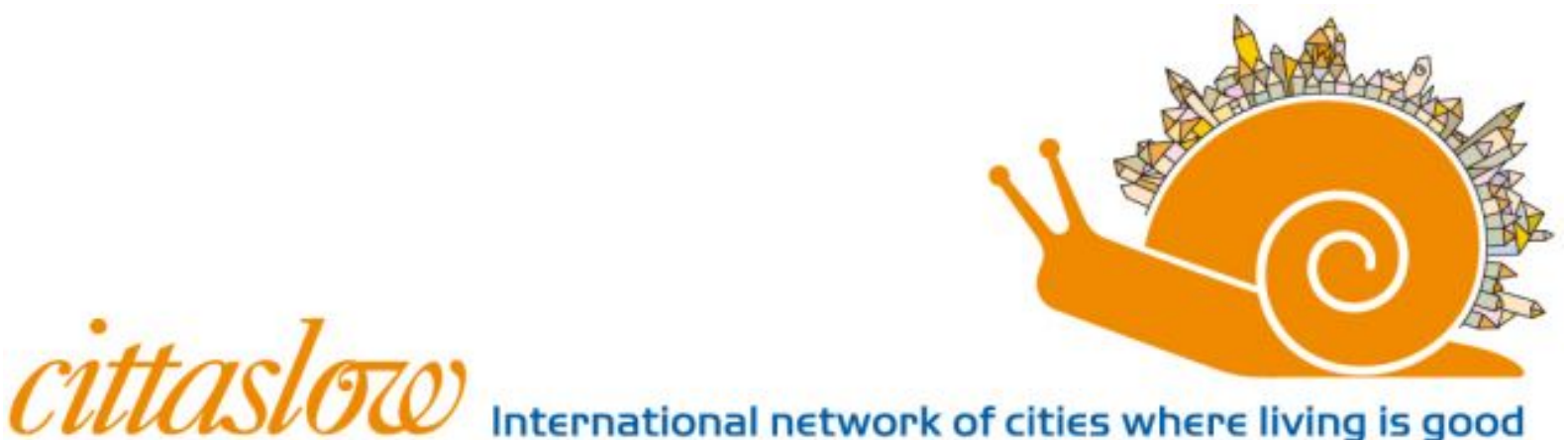

Şekil 1. Sakin Şehir Sloganı ve Logosu

Kaynak: www.cittaslow.org

Sakin şehir hareketinde bölgesel planlama yerel kimlik açısından ele alınmakta ve her kentin kendine özgü niteliklerinin korunduğu bir yerleşim yeri tasarlanmaktadır (Radstrom, 2011). Günümüzün ihtiyaçlarını gelecek nesillerin ihtiyaçlarını engellemeden karşılamayı amaçladığı için hareketin özü sürdürülebilir kalkınma ekseninde oluşmaktadır (Pink, 2008). Birleşmiş Milletler bünyesinde faaliyet gösteren Dünya Çevre ve Kalkınma Komisyonu tarafından yayınlanan Brundtland raporuna göre sürdürülebilir kalkınma en genel haliyle "gelecek kuşakların ihtiyaçlarını karşılayabilmesi olanağından ödün vermeksizin bugünün ihtiyaçlarının karşılanabilmesi" şeklinde ifade edilmiştir (Dinçer ve Can, 2016). Bu kavram, nüfus, kaynaklar, çevre ve kalkınma arasındaki karşılıklı ilişkilerin tam olarak bilinmesi, uygun şeklide düzenlenmesi ve bunlar arasında uyumlu, dinamik bir denge kurulması gerektiğini savunmaktadır. Bu açıdan sürdürülebilir kalkınma; çevresel, ekonomik ve sosyal boyutları olan bir anlayıştır (Kahraman ve Türkay, 2011).

Sürdürülebilirliğin her boyutu sakin şehir kavramına uyarlandığında bu hareket sürdürülebilir kalkınma, sürdürülebilir şehircilik ve sürdürülebilir turizm anlamına gelmektedir. Çünkü bu hareket aynı zamanda ekonomik kaynaklarını koruyan, sosyal açıdan güçlü ve çevreye duyarlı bir şehircilik ve turizm anlayışına sahiptir (Karadeniz, 2014: 85). Sürdürülebilir turizm ve sakin şehir uygulamaları sosyo-ekonomik ve kültürel gelişimleri adına kasabalar için yerel kalkınma stratejisi olarak gün geçtikçe önem arz etmektedir (Yllmaz, 2016). Sakin Şehir Hareketi, sürdürülebilir turizmin gelişimi için alternatif bir yaklaşım olarak tasarlanmıştır (Jung vd., 2014). Sakin Şehir üyeliği için çevre politikaları, altyapını sağlanması, kent dokusunun korunması, yerel üretimin ve ürünlerin desteklenmesi ve konukseverlik gibi koşulların yerine getirilmesi gerekmektedir. Sürdürülebilir turizmin amacı da önceliklerin yerel halka verilerek turizm planlamasının çevreye, topluma, tarihsel, doğal ve kültürel varlıklara zarar vermeden yöre ekonomisine ve bölge sakinlerinin yaşantısına katkı sunacak şekilde geliştirilmesidir. $\mathrm{Bu}$ açıdan sürüdürülebilir turizmin ilkeleriyle Sakin Şehir Hareketinin kriterleri paralellik göstermektedir (Karadeniz, 2014; Güneş, 2015).

$\mathrm{Bu}$ bilgiler ışığında sakin şehir unvanı alabilmek için belirli kriterleri yerine getiren şehirlerin aynı zamanda turizm açısından sürdürülebilir yerel kalkınma yolunda da ilerleme kaydetmiş olmaları beklenmektedir. Bu bağlamda 2009 yılından bu yana belediyelerin girişimiyle sakin şehir unvanını alan yerleşim yerlerinde bu girişimin yansımalarını ortaya çıkarmak, sakin şehir hareketinin turizm açısından şehirlerin sürdürülebilirliğine olan etkisini belirlemede büyük önem arz etmektedir. Bu açıdan çalışma sürdürülebilirliğin boyutları bağlamında Taraklı ve Yalvaç halkının sakin şehir hareketinin yansımaları konusundaki düşüncelerini metaforik açıdan ölçmeyi amaçlamaktadır. $\mathrm{Bu}$ sayede hereketin amacına ulaşıp ulaşmadığı noktasında fikir edinilmesi beklenmektedir. 


\section{YÖNTEM}

Nitel araştırma yöntemiyle yürütülen bu çalışmada durum çalışması araştırma yaklaşımı tercih edilmiştir. Durum çalışması araştırma yaklaşımı, araştırmacının gerçek yaşam, güncel sınırı bir durum ya da belli zamanda dilimindeki çoklu durumlar hakkında bilgi kaynakları aracılığıyla detaylı ve derinlemesine bilgi topladığı bir durum betimlemesi ya da durum temaları ortaya çıkardığı nitel bir yaklaşımdır (Creswell, 2013). Bu çalışmada sakin şehir unvanına sahip Taraklı ve Yalvaç destinasyonlarının sürdürülebilir yerel kalkınma yolunda geldiği noktayı karşılaştırmalı olarak ortaya çıkarmak amaçlanmıştır. Bu amaç doğrultusunda sakin şehir logosu olan salyangoz metaforu kullanılarak yerel halkın algısı üzerinden veri toplanmıştır. Metafor "insanların hayatı, çevreyi, olayları ve nesneleri nasıl gördüklerini farklı benzetmeler kullanarak açıklamaya çalışırken kullandıkları bir araç" şeklinde tanımlanabilir (Aydın, 2010: 1295). Araştırmaya ilişkin verilerin toplanabilmesi için nitel araştırma yöntemi kapsamında yer alan yarı yapılandırılmış görüşme tekniği kullanılmıştır. Yarı yapılandırılmış görüşme tekniğinde görüşmeci genel hatlarıyla bir yol haritasına sahiptir ancak katılımcının ilgi ve bilgisine göre bu genel çerçeve içerisinde farklı sorular sorarak konunun farklı boyutlarını da ortaya çıkarabilecek esnekliğe sahiptir (Altunışık, 2010). Bu açıklamalar ışığında sakin şehir logosunu ve sürdürülebilirliğin çevresel, sosyal ve ekonomik boyutlarını içeren açık uçlu sorular ile katılımcılara ait demografik verileri içeren kapalı uçlu soruların yer aldığı görüşme formu hazırlanmıştır.

Araştırmada amaçlı örnekleme yöntemlerinden kolay ulaşılabilir durum örneklemesi tercih edilmiştir. Buna göre araştırmacı yakın ve erişilmesi kolay olan bir durumu seçer. Ayrıca nitel araştırmalarda maliyet ve ulaşılabilirlik örneklem tercihinde dikkate alınması gereken etkenlerdir (Yıldırım ve Şimşek, 2018). Bu koşullar altında araştırmacıya en yakın sakin şehirler olan Sakarya'nın Taraklı ve Isparta'nın Yalvaç ilçeleri araştırmanın yapılacağı yerler olarak tercih edilmiştir. Ayrıca Taraklı́nın 2011 ve Yalvaç'ın 2012' de sakin şehir unvanını alarak en eski sakin şehirler arasında yer almaları da diğer bir tercih sebebidir. Çünkü sakin şehirler, kriterlere uygun hareket edip etmediklerini tespit etmek amacıyla 5 yılda bir denetlenirler (www.cittaslow.org). Bu durum Taraklı ve Yalvaç'in kriterler doğrultusunda hareket eden iki sakin şehir olduğunu ortaya koymaktadır. Bu kapsamda Taraklı'da 16.11.2019 tarihinde 6 kişi, Yalvaç'ta 17.11.2019 tarihinde 6 kişi olmak üzere toplamda 12 kişiden ses kayıt cihazıyla veri toplanmıştır. Katılımcı sayısının bu şekilde belirlenmesinin sebebi de yarı yapılandırılmış görüşme tekniğine uygun olarak genel kabul gören kişi sayısının 12 kişi olmasıdır (Onwuegbuzie ve Collins, 2007). Ayrıca etik açıdan sorun olmaması için "katılımcı gönüllülük formu" oluşturulmuş ve görüşülen 12 kişiden araştırmaya gönüllü olarak katıldıklarına dair form doldurmaları istenmiştir. Taraklı'da yapılan görüşmelerde katılımcılar T1, T2, .., T6 şeklinde kodlanırken Yalvaç'ta yapılan görüşmelerde katılımcılar Y1, Y2, ..., Y6 şeklinde kodlanmıştır. Ses kayıt cihazıyla elde edilen veriler bilgisayar ortamında deşifre edilip düzenlenerek betimsel analize tabi tutulmuştur.

\section{BULGULAR}

\section{Demografik Yapıya İlişkin Bulgular}

Araştırmada sorulan ilk soru "Sakin şehir logosunu tarif edebilir misiniz?" şeklinde olmuştur. Bu soruya olumlu cevap veren katılımcılarla görüşmeye devam edilirken, olumsuz yanıt verenlerle görüşme sonlandırılmıştır. Böylece her bir şehirde 6 olarak belirlenen katılımcı sayısına ulaşmak için toplamda 
kaç kişiyle görüşme yapıldığı da önemli bir veri olarak kaydedilmiştir. Bu durum sakin şehir olma kriterleri arasında zorunlu olarak yerine getirilmesi gereken "şakin şehir konusunda kent sakinlerinin sürekli ve sistematik bir şekilde bilgilendirilmesi" kriterinin ne seviyede yerine getirildiğine de oransal olarak ışık tutmaktadır. Buna göre sakin şehir konusunda fikri olan 6 katılımcıya ulaşmak için Taraklı'da 9 kişiyle görüşülmüş buna karşın Yalvaç'ta 17 kişiyle görüşülmüştür. Araştırma sonunda görüşülen 12 kişiye ilişkin demografik veriler Tablo 1'de sunulmuştur.

Tablo 1. Katılımciların Demografik Verileri

\begin{tabular}{|c|c|c|c|c|c|c|}
\hline Kod İsim & Cinsiyet & Yaş & $\begin{array}{c}\text { Eğitim } \\
\text { Durumu } \\
\text { (Mezun) }\end{array}$ & Meslek & Aylık Gelir & $\begin{array}{c}\text { Taraklı/Yalvaç'ta } \\
\text { yaşadığı süre }\end{array}$ \\
\hline $\mathrm{T} 1$ & Kadın & 21 & Lise & İşçi & $2020 \mathrm{TL}$ & 7 yil \\
\hline $\mathrm{T} 2$ & Erkek & 28 & Lisans & Pazarlama & $2500 \mathrm{TL}$ & 28 yıl \\
\hline T3 & Kadın & 46 & Lise & Esnaf & $6000 \mathrm{TL}$ & 12 yıl \\
\hline $\mathrm{T} 4$ & Erkek & 27 & Önlisans & $\begin{array}{c}\text { Satış } \\
\text { Temsilcisi }\end{array}$ & $2020 \mathrm{TL}$ & $20 \mathrm{yll}$ \\
\hline $\mathrm{T} 5$ & Erkek & 31 & Lisans & Turizm & $3000 \mathrm{TL}$ & $12 \mathrm{y} 1 \mathrm{l}$ \\
\hline T6 & Kadın & 43 & Lise & $\begin{array}{l}\text { Serbest } \\
\text { Meslek }\end{array}$ & - & $10 \mathrm{yll}$ \\
\hline $\mathrm{Y} 1$ & Erkek & 43 & Önlisans & Esnaf & - & 43 yıl \\
\hline $\mathrm{Y} 2$ & Erkek & 57 & Lise & Emekli & $2400 \mathrm{TL}$ & $16 \mathrm{yll}$ \\
\hline Y3 & Erkek & 48 & Lise & $\begin{array}{c}\text { Devlet } \\
\text { Sanatçısı }\end{array}$ & - & 48 yıl \\
\hline$Y 4$ & Erkek & 40 & Lisans & Esnaf & $3500 \mathrm{TL}$ & $36 \mathrm{yll}$ \\
\hline Y5 & Erkek & 65 & Ortaokul & Emekli & - & $65 \mathrm{y} 1 \mathrm{l}$ \\
\hline Y6 & Kadın & 38 & Lise & İşçi & $2020 \mathrm{TL}$ & 38 yıl \\
\hline
\end{tabular}

Tablo 1'deki veriler incelendiğinde katılımcıların 8'i erkek, 4'ü kadın olduğu görülmektedir. Farklı yaş gruplarını temsil eden katılımcların 1'i ortaokul, 6'sı lise, 2'si önlisans, 3'ü lisans mezundur. Yine farklı meslek gruplarında yer alan katılımcıların ortalama bir gelire sahip olduğu görülmektedir. Son olarak 11 katılımcı yaşadığı şehre o şehrin sakin şehir unvanını almasından çok daha uzun bir süre önce yerleşmişken sadece1 katılımcı bulunduğu şehre sakin sakin şehir olduktan bir yıl sonra yerleşmiştir.

Demografik bulguları yorumlamak gerekirse cinsiyet açısından en çok dikkati çeken nokta Taraklı'da görüşmelere katılım eşit dağılım sergilerken Yalvaç'ta sadece bir kadın katılımcıyla görüşme yapılabilmiştir. Bu açıdan kadınların sosyal hayata dâhil olması noktasında Taraklı'nın daha iyi bir noktada olduğu ileri sürülebilir. Katılımcıların yaşları açısından Taraklı'da yaş ortalaması yaklaşık değerlerle 33 iken Yalvaç'ta 48 olarak tespit edilmiştir. Bu açıdan Yalvaç'ın göç veren bir şehir olduğu ileri sürülebilir. Meslek açısından her iki şehirdeki katılımcıların daha çok ticari faaliyetler kapsamında istihdam edildikleri tespit edilmiştir. Bu bağlamda şehirlerde ticaretin geliştirilmesi ve ekonomik sürdürülebilirliğin sağlanması yereldeki halklar için büyük önem arz etmektedir. Çalışmanın bulguları yerel halkın şehirde yaşadığı sürenin, Yalvaç'taki katılımcıların yaşları ile yakın seviyelerde olduğunu göstermektedir. Buna karşın Taraklı'daki katılımcıların yaşları ile şehirdeki yaşam süreleri arasında 
belirgin bir fark olduğu görülmektedir. Bu açıdan Taraklı'nın göç alan bir sakin şehir olduğu iddia edilebilir.

\section{Sürdürülebilir Kalkınmanın Ekonomik Boyutuna İlişkin Bulgular}

Araştırmaya katılan kişilerden öncelikle sakin şehri logosuyla yereldeki ekonomik faaliyetleri ilişkilendirmeleri ve daha sonra bu durumun yaşadıkları şehirdeki ekonomik faaliyetleri yansıtıp yansıtmadığını dile getirmeleri istenmiştir. "Sakin şehir logosuyla ilişkilendirerek bir şehrin ekonomisini nasıl tasvir edersiniz? Bu durum sizin şehrinizi yansıtıyor mu?" sorusuna katılımcılardan gelen dikkati çeken cevaplar aşağıda sıralanmıştır:

T5: "Salyangoz bana göre çeşitliliğin az, sabit ürünlerin üzerinden yürüyen bir ekonomiyi ifade ediyor. İstihdam açısından ise personel devir hızının yavaş olduğu tabi bu da nüfusa dayalı bir şey. Yani aslında işin ve üretimin daha organik ve doğal ancak üretimin daha az devirde ve seri üretimin olmadığını söyleyebilirim." "Aynı şekilde bu durumun Taraklı'yı yansıttı̆̆ını düşünüyorum. Çünkü sakin şehir ilan edildikten sonra kültürrel ve yöresel ürünlerin değerlerin daha çok önemsendiğini ve ön plana çıktığını söyleyebilirim."

T6: "Yani birçok sorumluluğu taşıyor gibi geliyor. Yani ekonomi günümüzde çok hızl hep bir koşturmaca ama Taraklı'da daha yavaş sakin gidiyor bu işler. Bu açıdan Taraklı salyangozun sakinliğini yansıtıyor."

T1: "Yani ben bu şekilde sessiz olarak seçilen yerlerin ekonomisinin çok ileri seviyede olduğunu düşünmüyorum. Turizm açısından zamanla gelişebilir çünkü artık Cittaslowa dâhil olmuş. Yani Taraklı gibi küçük yerler tercih ediliyor. Yani ekonomik açından büyük şehirlere oranla daha düşük bir gelişim var diyebiliriz. Yerel üretimin artması açısından mesela burada haftada 10 paket tereyağı yapan bir insan şuanda 30 paket yapıyor olabilir. Yani bu açıdan yerel ürünlerin üretiminde de bir artış oldu."

Y3: "Sakin şehir logosu Yalvaç'ı yansıtmıyor. Bizim Yalvaç Akdeniz bölgesinde tek. Semercisi, keçecisi, el sanatları, kalaycısı, halı dokumacısı, dericisiyle Akdeniz'de tek olan bir yer burası. Bunu bile değerlendiremedik yani. Hepsi unutuldu mesela sakin şehir unvanım aldığımızda Yalvaç'ta 12 tane keçeci vardı şimdi tek keçeci ben kaldım. Bu sakin şehir unvanı alan şehirlerin yıllık aidat ödemesi gerekirmiş. Bizim başkan o aidatı da ödememiş. Belki de bugün yarın bizi çıkarabilirler yani."

Y1: "Bura da bir antik kent var haberin var mı senin? Ha! Burada bir antik kent var. Roma zamanindan. Yani burası sakin şehir unvanını alırken bu tip değerlerle almıştır bence şimdi kültürel tarihsel değerlerimiz var bizim. Ta Romalılardan kalma hamamlar, pazar yerleri. Kiliseye Kore'den Japonya'dan 2-3 otobüs geliyor. Orada birkaç saat durup ayin yapıyorlar sonra da otobüse binip gidiyorlar. Eskiden çarşıya inerlerdi benden sigarasını, dondurmasın alırlardl. Böyle bir sıkıntı var onu fark ediyorum son 8-10 yıldır. Yani ne hikmetse sakin şehir olduktan sonra burası geriledi."

Y2: "Bence Yalvaç bu değil. Tabi bu yönetimle de alakalı burada liderlik vasfı yok. 20 bin nüfusu olan bir yerde ticaret odası olan bir yer. Bir esnaf ağırlı̆̆ımız var. Yani burada her şeyde bir durgunluk bir yavaşlama var. Ben memleketime 2003'te geri döndüm. 35bin nüfus vardı şimdi 20 bin nüfus var. Bizim sakin şehir denilen bir yaşamımız yok burada böyle bir logonun altına girmişiz ama boş yaşıyoruz burada. Ne artısı var ne eksisi var."

Yukarıdaki açıklamalar ışığında iki şehir arasında hem sakin şehir logosunun yarattığı algı hem de ekonomik sürdürülebilirlik açısından gözle görülür bir fark olduğu ileri sürülebilir. Bu bakımdan Taraklı' da yaşayan halk sakin şehir hareketinin özellikleri açısından Taraklı' daki ekonomik faaliyetleri 
yansıttığını düşünmektedir. Ayrıca yöredeki ekonomik faaliyetlerden faydalandıklarını ve bu duruma bağlı olarak memnuniyetlerini dile getirmektedirler. Buna karşın Yalvaç halkı sahip olduğu değerlere rağmen olumsuz anlamda ekonomik bir durgunluk içinde yaşadıklarını dile getirmektedir. Şehirler arasındaki bu farklılı̆̆ın sakin şehir unvanının alınmasından sonra hareketin etkilerinin ortaya çıması adına gerekli olan politikaları üretme ve uygulama noktasında ilçe belediyelerinin yaklaşımlarından kaynaklandığı ileri sürülebilir.

\section{Sürdürülebilir Kalkınmanın Çevresel Boyutuna İlişkin Bulgular}

Katılımcılardan sakin şehri logosuyla bir yerelin doğal çevresini ilişkilendirmeleri ve daha sonra bu durumun yaşadıkları şehri temsil edip etmediğini ifade etmeleri istenmiştir. "Sakin şehir logosuyla ilişkilendirerek bir şehrin doğal çevresini nasıl tasvir edersiniz? Bu durum sizin şehrinizi yansıtıyor mu?" sorusuna katılımcılardan gelen ve önemli görülen açıklamalar aşağıya aktarılmıştır. Buna göre:

T1: “Yani kasaba gibi daha küçük ve sessiz yerler, toprak yani bitki örtüsünün belki daha çok olduğu yerler olabilir. Yani turuncu rengiyle toprak rengi belki anlatıliyor. Yani evet ben bu açlardan salyangozun Tarakl şehrini yansıttığını düşüyorum."

T2: "Şimdi çok fazla yatırım yapılmayan sanayisi olmayan bir yer olduğu için ve yavaş ilerleyen bir yer olduğu için de baktığınız zaman doğayla barışık bir kasaba. Çünkü havası çok temiz yani en yakın çevre yolu bile buraya $30 \mathrm{~km}$ uzaklıkta bu sebeple arabanın egzoz gazı bile doğanın kirlenmesine müsaade etmeyen bir yer. Temiz bir doğaya sahip olması yani ilk başta aklıma bu geliyor."

T5: "Yani yerleşke ve bina olarak az, doğanın daha ön planda olmasından dolayı özdeşleştirebilirim. Bu açıdan, ben Taraklı'yı da yansıttığını düşünüyorum."

Y1: "Yani bence ne olumlu ne olumsuz değişen bir şey yok. Eskinden nasılsa şimdi de aynı. Bu işi buraya getiren belediye başkanıdır ama o bile bu işi halka anlatmadı. Ama Yalvaç'ta halkın yaptığı güzel bir şey var. Burada imza toplandı doğalgazı getirdi."

Y2: "Ya bak bizim burada dünyada tek olan Hristiyanlı̆̆ın ilk vaazının verildiğgi yere biz çöp döküyoruz hala. Turist geliyor buraya bizim belediyenin çöpü kilisenin kapısının önünde duruyor. Belediye oraya çöp döküyor. Yani ben daha bir şey demek istemiyorum bu kadar da olmaz ya."

Bulgular sürdürülebilir kalkınmanın çevresel boyutu açısından incelendiği zaman iki şehir arasında farklılıkların olduğu görülmektedir. Taraklı'daki katılımcların metaforik açıdan salyangozu doğal çevreyle doğru bir şekilde ilişkilendirebildiği ve Taraklı'da çevresel bir bozulmanın olmadığını dile getirdikleri görülmektedir. Buna karşın Yalvaç'taki katılımcılar hem doğal çevre hem de kültürel çevrenin korunması adına yerel otoritenin çevre bilinciyle hareket etmediğini ve bu durumdan kaynaklı duydukları rahatsızlığı ifade etmektedir. Her iki şehirde bu tür bir farklılığın oluşması ilçe belediyelerinin çevreyle ilgili sakin şehir kriterlerini hayata geçirme konusunda sergilediği yaklaşımdan kaynaklandığg ileri sürülebilir. 


\section{Sürdürülebilir Kalkınmanın Sosyal Boyutuna İlişkin Bulgular}

Araştırmaya katılan kişilerden sakin şehri logosunu yereldeki sosyal adalet, eşitlik ve kadınların iş gücüne katılması şeklindeki konularla ilişkilendirmeleri ve daha sonra bu durumun yaşadıkları şehirdeki sosyal durumu yansıtıp yansıtmadığını dile getirmeleri istenmiştir. "Sakin şehir logosuyla ilişkilendirerek bir şehrin sosyal adalet, eşitlik ve kadınların iş gücüne katılmasını nasıl tasvir edersiniz? Bu durum sizin şehrinizi yansıtıyor mu?" sorusuna katılımcılardan gelen kayda değer cevaplar şu şekildedir:

T3: "Ağır adımlar, emin adımlar ve biraz da güç. Tabi birde üzerindeki evlerle tarihi dokuyu vermişler. Yani bakın bundan 5-6 sene önce Taraklı'da alt çarşı kavramı çok azdı. Yani kadınların çalıştığı yer. Ama bugün kadınlar evde değil artık dışardalar. İşte yöresel ürünlerini satıyorlar genel anlamda ama bu da sakin şehirle birlikte geldi."

T1: "Yani buralarda biri asgari ücret alırken bir başkası 15bin maaş almaz yani bana bu açıdan eşitliği ifade ediyor. Ayrıca adli olayların düşük olması mesela dikkate alınabilir. Ancak kadınların iş sahibi olmasına yönelik çok katkısının olduğunu düşünmüyorum."

T4: "Şimdi bakıldığı zaman herkesin eşit gelirlere sahip olduğunu ifade ediyor. Taraklıda da herkes bu duruma uyuyor. Yani halk eşit ne çok zengini var ne de çok fakiri var. Yani ya esnaftır ya hayvancllıkla ve tarımla uğraşır."

T5: "Belirli bir kesim için geçerli olabilir çünkü birisi bir işe başlayıp kendini geliştirmişse o iş o kişilerin elinde kalmış. Tekrar ona rakip olacak kişiler ortaya çıkmamış. Yani bir sürdürülebilirlik söz konusu, pazar rekabeti çok yok."

Y1: "Yani birilerini kayırma ben böyle bir şey Yalvaç'ta görmüyorum. Yani sakin şehir unvanını almışsak bir şeyler vardır burada. Bir özelliğimiz var demek ki bizim."

Y3: "Yani bu açıdan da bize bir katkısı olmadı. Kadınların istihdam edilmesine de etkisi olmadı. Biz sakin şehir logosunu aldık. Şehrin bir girişine taktık diğger girişinde o da yok. Bak bu işe gireli biz 7-8 sene oldu. Daha bir tane bir faaliyetimiz olmadr."

Y4: "Yani burada faaliyet gösteren mahalle firınlar var. O mahalle kadınlarında da kadınlar imece usulüyle çalışırlar. Yani kadınlar firında para karşılığı çalışmaz karşılı̆̆ında ihtiyacı olan ekmeği alır giderdi. Eskiden beri böyledir bu iş. Dışarıya da pek bir satış yoktu eskiden ama şimdi biraz satmaya başlamışlar. Ayrıca halkın bir pazarı var pazara gittiğinizde de yine kadınlarn görürsünüz. Bu tür yerlerde kadınların yeri hep vardı. Ama bunun sakin şehir olmasıyla bir ilgisi yok eskiden beri vardı."

Sürdürülebilir kalkınmanın sosyal boyutu açısından dikkati çeken en önemli bulgu şehirlerde sınıfsal açıdan büyük bir farklılığın oluşmaması ve katılımcıların gelir düzeyi bakımından benzer bir yaşam standardına sahip olduğunu dile getirmesidir. Kadınların iş gücüne dâhil olması konusunda ise Taraklı'daki katılımcılar sakin şehir hareketinin olumlu bir etkisi olduğunu ifade ederken, Yalvaç'taki katılımclar kadın istihdamı açısından sakin şehir hareketinden faydalanamadıklarını dile getirmektedir. Bu durum Yalvaç'ta geleneksel el sanatlarının ve yöresel lezzetlerin yeniden günümüze kazandırılması için ilgili otorite tarafından gereken girişimlerin yapılmadığını ortaya koymaktadır.

Son olarak şehirlerin özelliğini ve ihtiyaçlarını kendi sakinlerinin gözünden belirlemek amacıyla katılımcılardan yaşadıkları şehri, ekonomik faaliyetler, doğal çevrenin durumu ve sosyal özelliği bakımından tasvir etmeleri istenmiştir. "Tüm bu açılardan siz yaşadığınız şehri hangi hayvanla tasvir ederdiniz?" sorusuna katılımcılardan gelen dikkati çeken cevaplar şu şekildedir: 
T5: "Kaplumbağa olabilirdi. Çünkü rengi biraz daha yeşili ve doğayı anımsattığı için yine keza o da yavaş ve sakin, kalabalıktan uzak ve sürü şeklinde yaşamayan bir hayvan olduğu için kaplumbağa ile bağdaştırabilirim."

T4: "Yani yavaş olmasından dolayı kaplumbağa ile özdeşleştirirdim."

T1: "Ben olsam Taraklı için salyangoz aklıma ilk gelen hayvan olmazdı. Yani Taraklı'yı doğasıyla düşündüğüm zaman Sincap aklıma geliyor. Yani daha mütevazı ve masum bir hayvan geliyor. Yani bu tür yerlerde yırtıcı bir hayvan kullanmak olmaz bence."

Y1: "Salyangoz bunu temsil ediyordur tabi yani kaplumbağa olur salyangoz olur ama biz bunu değerlendiremedik. Bak Yalvaç İncil'in 12. sayfasında geçer. Hristiyanlığın Avrupa'ya yayılma merkezi burası. Aziz Paulos burada yaşamış. Ama bunu duyuramıyorlar işte."

Y2: "Ben çalşma ve üretimden yanayım. Üretime hangi hayvan uyuyorsa ben o logoyu isterim. Bu anlamda bizim önümüzü açacak bize önderlik edecek kimse yok. Elini taşın altına koyacak kimse yok. Bizim meşhur camızımız var. Onun ürettiği şekilde onun ürettiği kaymak da tek. Hala eski yöntemlerle doğal bir şekilde üretilir."

Y5: "Ben olsam ceylan olsun isterdim. Çünkü atak bir hayvandır. Yalvaç insanı da hep ataktır."

Taraklı ve Yalvaç'taki katılımcılardan gelen cevaplar incelendiğinde kaplumbağanın ön plana çıktığı görülmektedir. Kaplumbağanın salyangoz kadar yavaş olmasının yanı sıra yeşil renkte bir hayvan olması sebebiyle doğayı da yansıttığını düşünmeleri bu durumun nedeni olarak görülebilir. Sonuç olarak araştırmaya dâhil olan katılımcılar kaplumbağanın sakin şehirleri daha çok yansıttı̆̆ını düşünmektedirler.

\section{SONUÇ VE DEĞERLENDİRME}

Araştırma bulguları demografik açıdan sakin şehirler arasındaki farkı açıkça ortaya koymaktadır. Buna göre araştırmanın yürütüldüğü her şehirde 6 katılımcıya ulaşmak için görüşülen kişi sayısı bakımından Taraklı'da yaşayan halkın sakin şehir hareketi konusunda çok daha fazla bilgi sahibi olduğu görülmektedir. Yalvaç'taki Y1 ve Y2 kodlu katılımcıların bu işin yürütücü olan belediyenin ilgisizliğini dile getirmesi de bu sonucu destekler niteliktedir. Buna göre sakin şehir kriterleri arasında zorunlu kriter olarak yer alan "şakin şehir konusunda kent sakinlerinin sürekli ve sistematik bir şekilde bilgilendirilmesi" konusunda Taraklı belediyesinin yeterince çaba sarf ettiği ileri sürülebilir. Demografik yapıya ilişkin diğer dikkati çeken bir konu ise şerhirlerdeki kadın katılımcı sayılarıdır. Buna göre Taraklı'daki katılımcıların yarısı kadınken Yalvaç'taki katılımcıların sadece bir tanesi kadındır. Nitekim Yalvaç'ta araştırma süresince cinciyet bakımından dengenin sağlanması için gösterilen çaba görüşülen kişi sayısının da artmasına neden olmuştur. Bu açıdan kadınların iş hayatına atılmaları, karar alma süreçlerine dahil edilmeleri gibi sosyal konularda Taraklı şehrinin çok daha ileride olduğu ileri sürülebilir. Demografik yapı konusunda bir diğer göze çarpan bir diğer farklılık ise katılımcıların yaşları olmuştur. Buna göre Taraklı'da araştırmaya dahil olan katılımcıların Yalvaç'a kıyasla daha genç olduğu görülmektedir. Y2 kodlu katılımcının Yalvaç'ın uzun zamandır göç verdiğini dile getirmesi bu durumun nedeni olarak görülebilir. Ayrıca Y3 kodlu katılımcının bir çok geleneksel mesleğin artık kalmadığını da dile getirmesi göçün bir başka nedeni olarak ele alınabilir.

Sakin şehir anlayışıyla sürdürülebilir turizm arasındaki ilişki bakımından bu araştırmanın bulguları Karadeniz (2014) ve Güneş (2015)'in yaptıkları çalışmayı destekler nitelikte sonuçlar ortaya koymuştur. Y2 kodlu katılımcının Yalvaç'ta kilisenin etrafına çöp döküldüğünü dile getirmesi ya da Y3 kodlu 
katılımcının geleneksel el sanatlarının yok olmaya başladığını söylemesi sakin şehir kriterlerinin yerine getirilmediği anlamına gelmektedir. Aynı zamanda bu durumların bir destinasyon için çekicilik unsuru olması ve olumsuz şekilde seyretmesi destinasyonun sürdürülebilirliğini de tehlikeye sokmaktadır.

Araştırma sürdürülebilir yerel kalkınmanın boyutları bakımından sakin şehirler arasında farklılıkların oluğunu göstermektedir. Buna göre sürdürülebilirliğin ekonomik boyutu açısından Yalvaç'ta uzun bir süredir durgunluk olduğu saptanmıştır. Y1, Y2 ve Y3 kodlu katılımcıların ekonomik boyuta ilişkin Yalvaç'ta süre gelen olumsuzlukları dile getirmesi aynı zamanda sakin şehir kriterleri arasında yer alan "Kentsel canlılı̆̆ın sağlanması" ve "El yapımı ve etiketli zaanat üretiminin korunması" gibi önem arz eden kriterlerin de dikkate alınmadığı anlamına gelmektedir. Yalvaç' in aksine Taraklı'da yöresel ürünlere ve el sanatlarına dayalı yerel ekonomik faaliyetlerden halkın oldukça memnun olduğu görülmektedir. T1 ve T5 kodlu katılımclları sakin şehir süreciyle birlikte yerel ürünlerin daha çok önemsendiğini ve satışında da bir artış olduğunu dile getirmeleri bu durumun olumlu yansımalarını ortaya koymaktadır.

Sürdürülebilir kalkınmanın çevresel boyutu bakımından T1 ve T2 kodlu katılımcıların Taraklı için yapmış olduğu açıklamalar doğal çevrenin Yalvaç'a kıyasla Tarak'lının daha iyi durumda olduğu ileri sürülebilir. Bununla birlikte Y2 kodlu katılımcının “Turist geliyor buraya bizim belediyenin çöpü kilisenin kapısının önünde duruyor." şeklindeki açıklaması hem turizmin sürdürülebilirliğinin olumsuz yönde seyrettiğine hem de çevreyle ilgili sakin şehir kriterlerinin sağlanmadığına işaret etmektedir.

Sürdürülebilir kalkınmanın sosyal boyutu bakımından Yalvaç'taki katılımcıların yapmış olduğu açıklamalar ortak bir düşünceyi yansıtmamakta buna karşın Taraklı' daki tüm katılımcılar halkın eşit şartlarda yaşadığını, kadınların sosyal hayata dahil olduğunu ve suç oranlarının düşük olduğunu dile getirerek ortak bir düşünceyi savunmaktadırlar.

Son olarak "Ekonomik faaliyetler, sosyal yaşam ve doğal çevre bakımından siz yaşadığınız şehri hangi hayvanla tasvir ederdiniz?" sorusuna katılımcıların verdiği cevaplar incelendiğinde Taraklı için doğayla özdeşleştirilen ve yine sakin şehir felsefesiyle uyumlu olarak yavaş hareket eden kaplumbağa ön plana çıkmıştır. Buna karşılık Yalvaç'ın ataklığı ve üretkenliğiyle ön plana çıkan bir hayvanla tasvir edilmek istendiği görülmüştür. Bu tür bir benzetmenin sebebi Yalvaç'taki gerek sosyal yaşamın gerekse ekonomik faaliyetlerin durgunluk gösteriyor olmasına ve eski dönemlerin özlenmesine bağlanabilir. Yalvaç açısından dikkati çeken bir başka sonuç ise zorunlu olan ve şehir için önem teşkil eden sakin şehir kriterlerinin yeteri kadar uygulanmamış olmasına rağmen Yalvaç' ın 5 yıllık denetimden başarıyla geçmiş olmasıdır. Bu açıdan denetimlerin sıklaştırılması veya halkın da görüşleri alınarak bu denetimlerin yapılması daha doğru kararların verilmesine ışık tutacaktır. Yöre halkına böyle bir imkân tanınması halinde yöredeki otorite açısından doğal bir denge denetleme mekanizmasının oluşması sağlanacaktır.

Yalvaç belediyesi tarafından sakin şehir anlayışının halka daha çok anlatılması ve halkın sürece dâhil edilmesi gerekmektedir. Bu kapsamda geleneksel el sanat sanatları ve yöresel yiyeceklerin sunulmasına imkân veren pazarların kurulması hem yerel ekonominin hem de sosyal yaşamın hareketlenmesini sağlayabilir. Bu sayede her iki şehirde yaşayan yöre halkı arasında sosyo-ekonomik açıdan bir denge oluşması sağlanabilir. Taraklı açısından araştırmanın sonuçları açık bir şekilde göstermektedir ki sakin şehir hareketi Taraklı halkına doğru bir şekilde aktarılmış ve halk bu anlayışla yöresel ürünlerine ve geleneksel el sanatlarına sahip çıkarak bu durumdan fayda sağlamayı başarabilmiştir. Taraklının göstermiş olduğu bu başarı kendine özgü değerleriyle sakin şehir olma kriterlerini taşıyan bölgelerin 
bu unvana sahip olması için teşvik edici bir unsur olarak gösterilebilir. Böylece bu hareketin Türkiye'de faydalı çıktılar elde edecek şekilde yaygınlaştırılması sağlanabilir.

Sürdürülebilirliğin boyutları bağlamında sakin şehirler Yalvaç ve Taraklı'nın karşılaştırıldığı bu çalışma, diğer sakin şehirlere de uyarlanarak Türkiye'de sakin şehir anlayışının geldiği nokta oraya çıkarılabilir. Aynı şekilde sakin şehir olmaya uygun diğer şehirlerin de bu unvana sahip olması için alan araştırmaları yapılarak gerekli girişimler hayata geçirilebilir. Bu sayede unutulmaya yüz tutmuş yöreye özgü tarihi ve kültürel mirasın geleceğe aktarılması sağlanabilir. Bu durum aynı zamanda ülke genlinde kadınların iş gücüne ve sosyal hayata katılımı için önemli bir gerekliliktir. Bunun yanı sıra gerek sakin şehirlerde gerekse aday şehirlerde sosyo-ekonomik sürdürülebilirliğin sağlanması için yöreye özgü tüm değerlerin yeniden işletilmesi gerekmektedir. Bu sayede iş imkânlarının yetersiz olmasından kaynaklı şehirden göç eden gençlerin yöreye has değerlerden faydalanarak kendilerine bir hayat kurması sağlanabilir. Ayrıca aday şehirlerde sakin şehir unvanına sahip olmak için girişimlerde bulunurken Taraklı'nın kaydettiği ilerleme dikkate alınmalı ve sakin şehir süreci bu başarı örnek alınarak yürütülmelidir. Bu açıdan tüm sakin şehirlerde arzu edilen sonuçlara ulaşmak adına belediyelerin başarılı uygulamalarını birbirlerine aktarabilmeleri için belediyeler arası bir koordinasyon süreci başlatılabilir. Yine bu süreçte yerel halkın karar alma süreçlerine dâhil olmaları sağlanarak halkın sürece daha fazla sahip çıkması ve bu sayede daha verimli çıktıların alınması sağlanabilir.

\section{KAYNAKÇA}

Altunışık, R., Coşkun, R., Bayraktaroğlu, S., ve Yıldırım, E. (2010). Sosyal Bilimlerde Araştırma Yöntemleri. Sakarya: Sakarya Yayıncılık.

Andarabi, F. F. (2012). Cittaslow markasına sahip şehirlerde yerel halkın turizme yaklaşımı üzerine bir analiz: Seferihisar örneği. Yayınlanmamış doktora tezi. Ankara: Gazi Üniversitesi Eğitim Bilimleri Enstitüsü.

Aslan, E., ve Güneş, S. (2016). Sakin Şehirler için sürdürülebilir turizmin önemi Sakarya-Taraklı örneği. Journal of Recreation and Tourism Research, 3 (3): 1-17.

Aydın, F. (2010). Ortaöğretim öğrencilerinin coğrafya kavramına ilişkin sahip oldukları metaforlar. Kuram ve Uygulamada Eğitim Bilimleri, 10(3): 1293-1322.

Coşar, Y. (2013). Yavaş şehir (cittaslow) olgusunun turist davranışları ve yerel halkın kentsel yaşam kalitesi algısına etkileri. Yayınlanmamış Doktora Tezi, Dokuz Eylül Üniversitesi, İzmir.

Creswell, J. W. (2013). Nitel Araştırma Yöntemleri. (Çev: M. Bütün; S. B. Demir). London: Sage Publication.

Dinçer, D. İ., Ofluoğlu, M., ve Öz, M. (2015). Sürdürülebilirlik kapsamında sakin kent felsefesi ve yönetsel sorunlar: Halfeti örneği. Doğu Karadeniz Bölgesi Sürdürülebilir Turizm Kongresi. Gümüşhane Üniversitesi Yayınları. Gümüşhane. ss: 325-336

Dinçer, E. E., ve Can, A. (2016). Kentsel Yaşam ve Sürdürülebilirlik. İstanbul: Esenler Belediyesi Şehir Yayınları.

Dogrusoy, I. T. and Dalgakiran, A. (2011). An alternative approach in sustainable planning: Slow urbanism. International Journal of Architectural Research, 5(1): 127-142. 
Ekincek, S. (2014). Sakin şehir (Cittaslow) yöneticilerinin sakin şehir hareketine ve sürdürülebilirliğe yönelik değerlendirmeleri. Yayınlanmamış yükseklisans tezi, Anadolu Üniversitesi Sosyal Bilimler Enstitüsü, Eskişehir.

Güneş, G., Çalışkan Arısoy, E., ve Aslan, E. (2015). Cittaslow ağına dâhil kentler ve sürdürülebilir turizm kriterlerine yönelik bir analiz. Doğu Karadeniz Bölgesi Sürdürülebilir Turizm Kongresi. Gümüşhane Üniversitesi. Gümüşhane. ss: 311-324.

Güven, E. (2011). Yavaş güzeldir “yavaş yemek” ten "yavaş medya”ya hızlı tüketime dair bir çözüm önerisi. Selçuk İletişim Dergisi, 7(1): 113-121.

Jung, T., Ineson, E. and Miller, A. (2014). The slow food movement and sustainable tourism development. International Journal of Culture Tourism and Hospitality Research, 8(4): 432-445.

Kahraman, N. ve Türkay, O. (2011). Turizm ve Çevre. Ankara: Detay Yayıncllı.

Karadeniz, C. B. (2014). Sürdürülebilir turizm bağlamında sakin şehir Perşembe. Uluslararası Sosyal Araştırmalar Dergisi, 7(29): 84-107.

Markwell, K., Wilson, E. and Fullagar, S. (2012). Reflecting upon slow travel and tourism experiences, (Editör) S. Fullagar, K. Markwell, ve E. Wilson.: Slow tourism: experiences and mobilities içinde (s. 227-233). Bristol: Channel View Publications.

Miele, M. (2008). Cittàslow producing slowness against the fast life space and polity. Space and Polity, 12(1), 135-156.

Onwuegbuzie, A. J. and Collins, K. (2007). A typology of mixed methods sampling designs in social science research. The Qualitative Report, 12(2): 281-316.

Pink, S. (2008). Sense and sustainability The case of the Slow City. Local Environment, 13(2): 95-106.

Radstrom, S. (2011). A place sustaining framework for local urban identity an introduction and history of cittaslow. Italian Journal of Planning Practice, 1(1): 90-113.

Şahin, Z. (2017). Aktüel turizm türü olarak cittaslow organizasyonu, Türkiye ve dünyadaki örnekleriyle cittaslow faaliyetlerinin pazarlaması açısından bir SWOT analizi. Yayınlanmamış Yükseklisans Tezi, Beykent Üniversitesi Sosyal Bilimler Enstitüsü, İstanbul.

Sander-Regier, R. (2004). In the spirit of Noah, food iversity and the slow food movement. The Canadian Organic Grower, Fall, 10-15.

Semmens, J. and Freeman, C. (2012). The value of Cittaslow as an approach to local sustainable development: A New Zealand perspective. International Planning Studies, 17(4): 353-375.

Sırım, V. (2012). Çevreyle bütünleşmiş bir yerel yönetim örneği olarak "sakin şehir" hareketi ve Türkiye'nin potansiyeli. Tarih Kültür ve Sanat Arastırmaları Dergisi, 1(4): 119-131.

Tranter, P. J. (2010). Speed kills: The complex links between transport, lack of time and urban health. Journal of Urban Health: Bulletin of the New York Academy of Medicine, 87(2): 155-166.

UNEP. (2003). Tourism and local agenda 21: The role of local authorities in sustainable tourism. United Nations Publication, France. 
Ünal, M., ve Zavalsız, Y. (2016). Küreselleşme karşıtı bir hareket yavaş hareketi. İnsan ve Toplum Bilimleri Araştırmaları Dergisi, 5(4): 889-912.

www.cittaslow.org. Erişim Tarihi: 27.10.2019

www.slowfood.com. Erişim Tarihi: 27.10.2019

Yıldırım, A. ve Şimşek, H. (2018). Sosyal Bilimlerde Nitel Araştırma Yöntemleri. Ankara: Seçkin Yayıncılık.

Yılmaz, A., Tuncer , M. ve Zorlu, K. (2016 ). Yavaş Şehir (sürdürülebilir yerel kalkınma) potansiyelinin belirlenmesine yönelik bir araştırma: Güzelyurt, Aksaray. Studies of the Ottoman Domain, 6(10): 1-18.

Yurtseven, H. R.; Kaya, O. ve Harman, S. (2010). Yavaş Hareketi. Ankara: Detay Yayıncılık. 